\title{
PREEMPTIVE RIGHTS \\ AND THE SALE OF RESOURCE PROPERTIES: PRACTICAL PROBLEMS AND SOLUTIONS
}

\section{KEITH T. SMITH and SHAWN H.T. DENSTEDT ${ }^{*}$}

\begin{abstract}
Increasing asset rationalization in the oil and gas industry has led to a proliferation of preemptive rights issues which must be addressed by oil and gas lawyers. In this article. the authors examine the legal issues and practical problems related to preemptive rights. highlighting the uncertainty faced by parties involved in asset transactions.
\end{abstract}

\section{TABLE OF CONTENTS}

I. INTRODUCTION ................... 58

II. THE NATURE OF PREEMPTIVE RIGHTS $\ldots \ldots \ldots \ldots \ldots \ldots 58$

III. EXCEPTIONS TO PREEMPTIVE RIGHTS $\ldots \ldots \ldots \ldots \ldots \ldots 61$

A. ALL OR SUBSTANTIALLY ALL $\ldots \ldots \ldots \ldots \ldots \ldots 62$

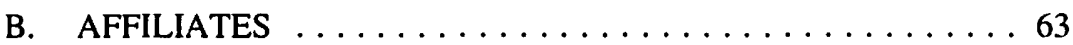

C. SECURITY FOR INDEBTEDNESS $\ldots \ldots \ldots \ldots \ldots \ldots 65$

IV. NOTICE AND THE DUTY TO

ACQUIRE KNOWLEDGE $\ldots \ldots \ldots \ldots \ldots \ldots \ldots \ldots \ldots \ldots \ldots \ldots \ldots \ldots \ldots$

A. THE COMMON LAW POSITION $\ldots \ldots \ldots \ldots \ldots \ldots 66$

B. THE ALBERTA LAND TITLES ACT $\ldots \ldots \ldots \ldots \ldots \ldots 7$

V. DEFENCES AGAINST PARTY HOLDING

A PREEMPTIVE RIGHT $\ldots \ldots \ldots \ldots \ldots \ldots \ldots \ldots \ldots$

A. THE RULE AGAINST PERPETUITIES $\ldots \ldots \ldots \ldots \ldots 68$

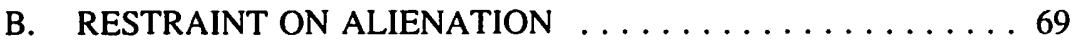

C. LIMITATION PERIODS $\ldots \ldots \ldots \ldots \ldots \ldots \ldots \ldots \ldots$

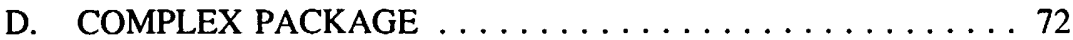

E. UNMATCHABLE CONSIDERATION $\ldots \ldots \ldots \ldots \ldots \ldots 73$

F. EQUITABLE DEFENCES $\ldots \ldots \ldots \ldots \ldots \ldots \ldots \ldots 74$

VI. REMEDIES AVAILABLE TO A PARTY

HOLDING A PREEMPTIVE RIGHT $\ldots \ldots \ldots \ldots \ldots \ldots \ldots 76$

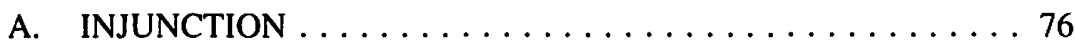

B. SPECIFIC PERFORMANCE $\ldots \ldots \ldots \ldots \ldots \ldots \ldots 77$

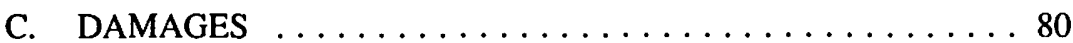

VII. PRACTICAL PROBLEMS $\ldots \ldots \ldots \ldots \ldots \ldots \ldots \ldots \ldots$

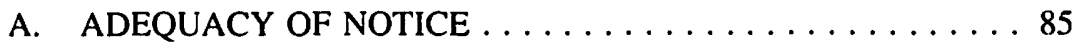

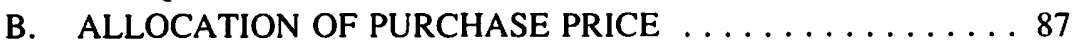

C. TRUSTEE, AGENT HOLDING THE RIGHT $\ldots \ldots \ldots \ldots 88$

D. LANDS AND TANGIBLES SPLIT $\ldots \ldots \ldots \ldots \ldots \ldots \ldots 89$

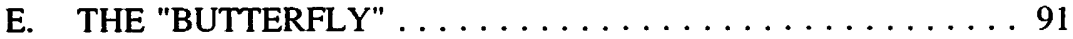

F. ASSIGNMENT OF A PREEMPTIVE RIGHT $\ldots \ldots \ldots \ldots 92$

VIII. CONCLUSION $\ldots \ldots \ldots \ldots \ldots \ldots \ldots \ldots \ldots \ldots \ldots \ldots \ldots$ 
[VOL. XXX, NO. 1 1992]

\section{INTRODUCTION}

Stagnant oil prices and ever-increasing administrative costs have forced the Canadian oil and gas industry to undergo a process of asset rationalization. In an effort to reduce debt or increase efficiency, and thus become more competitive, resource corporations identify and attempt to acquire greater interests in core assets while disposing of non-core assets. Assets are disposed of for cash, shares or other assets. A significant percentage of these properties are subject to preemptive rights and the sheer volume of transactions has meant that oil and gas lawyers are increasingly confronted with preemptive rights problems. The major part of this paper provides a brief summary of the existing common and statutory law applicable to preemptive rights. This summary is not intended as a detailed discussion of the reasoning behind the authorities reviewed but is intended to identify preemptive rights issues and the relevant authorities. The last section addresses a number of practical problems pertaining to preemptive rights and suggests potential solutions to these problems.

\section{THE NATURE OF A PREEMPTIVE RIGHT}

The nature of a preemptive right was conclusively established (and a long history of uncertainty' resolved) in Canadian Long Island Petroleums Ltd. v. Irving Industries Ltd. ${ }^{2}$ The plaintiff (respondent) and defendant (appellant) both had an interest in certain oil properties. They had entered into a farmout agreement under which each was given a right of first refusal if the other received a bona fide offer for all or a portion of its participating interest which it was willing to accept. The clause was "designed to protect the desire of each of the joint owners that it should not be forced into a joint ownership with another party against its will". ${ }^{3}$ The defendant offered to sell its interest to a third party who had knowledge of the preemptive right before if accepted the offer. Although the plaintiff attempted to exercise the right, the defendant conveyed its interest to the third party.

The defendants argued that the clause created an equitable interest in land which might not vest until after the period limited by the rule against perpetuities. The Court reviewed a number of relevant decisions and considered the differences between an option and a preemptive right. Martland J., speaking for the Court, indicated that the essence of an option to purchase is that upon the granting of the option the optionee can, upon the

1. For an abbreviated historical review of the English and Canadian authorities which consider the legal characterization of options, rights of repurchase and preemptive rights and whether these rights constitute interests in land, see: Birmingham Canal Company v. Carrwright (1877), 11 Ch. D 421; London and South Western Railway Company v. Gomm (1882), 20 Ch. D 562; Manchester Ship Canal Company v. Manchester Racecourse Company, [1901] 2 Ch. D 37 (C.A.); Re Albay Realty Limited and Dufferin - Lawrence Developments Limited. [1956] O.W.N. 302 (Ont. H.C.); Frobisher Limited v. Canadian Pipelines \& Petroleums Limited et al, [1960] S.C.R. 126; City of Halifax v. Vaughan Construction Company Limited and the Queen, [1961] S.C.R. 715; Murray v. Two Strokes Lid., [1973] 3 All E.R. 357. S.C.R.].

3. Ibid. at 728 . 
occurrence of certain events solely within his control, compel a conveyance of the property to him. A preemptive right does not give the holder a present right to compel a future conveyance, and is not specifically enforceable at the time the agreement is executed. ${ }^{4}$ The right is a contractual one subject to a contingency based solely on the decision of another party to sell. The preemptive right is transformed into an option to purchase only when the party who gave the contractual covenant is prepared to accept an offer to sell its interest (and then only on the terms of that offer). Martland J. stated that considerations of public policy which give rise to the rule against perpetuities did not exist as there was no interest in land. Martland J. concluded that the right was a negative covenant:

In my opinion the right conferred by cl. 13 of the agreement in question here did not create property rights. Each party agreed that upon the occurrence of a certain event, which was within its own control, the other party would have a first right of purchase for a 30 day period. As mentioned previously, the clause is a part of an agreement between joint owners of a property, governing the operation and development of it. In essence it is a negative covenant whereby each party agrees not to substitute a third party as a joint owner with the other, without permitting the other party the opportunity, by meeting the proposed terms of sale, to acquire full ownership.'

Martland J.'s distinction between an "option" and a "right of first refusal" in the Long Island Petroleums case has been accepted by a number of cases. ${ }^{6}$

McFarland v. Hauser ${ }^{7}$ is another important decision of the Supreme Court of Canada dealing with preemptive rights. In McFarland the plaintiff entered into a lease agreement with the defendant which included a right of first refusal. A caveat was filed to protect the lease. Subsequently, the defendant was approached by a purchaser who was granted an option to purchase. He was told of, and given a copy of, the lease with the plaintiff. The plaintiff became aware of the agreement, purported to exercise his right of first refusal and raised funds to buy the property. The optionee filed a caveat to protect his option and served notice on the plaintiff to defend his caveat. The plaintiff's caveat lapsed because he failed to file a lis pendens. The Supreme Court of Canada granted specific performance to the plaintiff, overtuming the decision of the Alberta Court of

4. However, see P.M. Perell, "Options, Rights of Repurchase and Rights of First Refusal as Contracts and as Interests in Land" (1991) 70 Can. Bar Rev. 1. Perell argues that the fact specific performance is not available as a remedy is not conclusive proof that a property right does not exist at the time an agreement is executed. He argues that because injunctive relief may be available to the preemptive right holder a property right may exist from the moment the agreement is executed.

Supra, note 2 at 735.

6. Stephens v. Gulf Oil Canada Lid. (1975), 65 D.L.R. (3d) 193; Re McKee and National Trust Co. Ltd. et al (1975), 7 O.R. (2d) 614, 56 D.L.R. (3d) 190; Politzer v. Metropolitan Homes Lid. (1975), 54 D.L.R. (3d) 376, [1975] 5 W.W.R. 492, 3 N.R. 621; Re Essex County Roman Catholic Separate School Board (1977), 2 R.P.R. 223 (Ont. S.C.); Roberts v. Hanson (1980), 28 A.R. 287 (Alta. Q.B.); Masai Minerals Limited v. Heritage Resources Lid., [1981] 2 W.W.R. 140; Western Oil Consultants v. Great Northern Oils LId. (1981), 121 D.L.R. (3d) 724; Marino v. Min. Transport and Communications (1982), 26 L.C.R. 372; Canada Trustco Mortgage Company v. Skoretz, [1983] 4 W.W.R. 618.

7. (1978), 7 Alta. L.R. (2d) 204, appeal all'd from (1977), 2 Alta. L.R. (2d) 289, 3 A.R. 449 [hereinafter "McFarland"]. 
Appeal. The optionee contended that the provisions of the Alberta Land Titles Act, ${ }^{8}$ protected the priority of his caveat. Following the lapse of the plaintiff's caveat, the Land Titles Act gave the option priority over the plaintiff's rights. The optionee also contended that because mere knowledge of a competing right does not constitute fraud, his position was not affected by his knowledge of the existence of the plaintiff's right. McGillivray C.J.A. agreed with this contention in the Alberta Court of Appeal, distinguishing the decision in Long Island Petroleums. The following passage deals concisely with this issue:

\footnotetext{
Now, in the Can. Long Island case, on the facts of that case it was held that a right of first refusal is not an interest in land, but that the court could, through the exercise of its equitable jurisdiction, reach one who is purporting to deal with the land with knowledge of the right of first refusal. The Land Titles Act was not involved in the Can. Long Islands case. In the case of land registered under the Land Titles Act. as here, it then would be a remarkable result, and, indeed one which would very much disturb the entire land titles system of this province to hold that, while a purchaser who dealt with a registered owner was not affected by earlier knowledge, he was not affected by personal covenants, and equity could reach him in spite of the provisions of $\mathbf{5 . 2 0 3}$ of the Land Titles Act. In my view, a purchaser of land who acquires land without fraud from a registened owner acquires free from any claim in equity, whether the claim be advanced in personam or in rem. To hold otherwise would mean that a purchaser who deals with a registered owner with knowledge or claims of others, could not have the certainty he now enjoys of knowing that he will get a title which is indefeasible."
}

Morrow J.A. was the only other judge who considered this point (Moir J.A. concurring) and added that the plaintiff could not have filed a caveat originally, because his right of first refusal was not an interest in land. ${ }^{10}$

The Supreme Court of Canada based its decision on the explicit terms of the agreement between the parties and indicated that the optionee had more than "mere notice" of the plaintiff's interest. The Court stated that the optionee had been told of the right of first refusal and received a copy of the lease before the option was exercised; moreover, the option agreement was specifically stated to be subject to the lease, and, as such, was subject to the right of first refusal. Martland J. relied upon St. Mary's Parish Credit Union Ltd. v. T.M. Ball Lbr. Co." where the Court stated that the filing of a caveat against an interest could not create a charge upon more than that which had been charged by the interest itself. He concluded:

Sunderland is not entitled to succeed by virtue of s. 203 of the Land Tilles Act. This is not a case of a purchaser acting in reliance upon the register although actually aware of a prior unregistered interest. In the present case, Sunderland was not only aware of McFarland's interest when he obtained the interest from Hauser, the option itself was made subject to that interest and he is not entitled to obtain from

R.S.A. 1970, c. 198. The optionee relied on sections 136, 152 and 203. Similar provisions are contained in the current Land Tilles Act, R.S.A. 1980, c. L-5.

(1977), 2 Alta. L.R. (2d) 289 at 317.

Ihid. at 352-53.

[1961] S.C.R. 310. (1961), 34 W.W.R. 625. 
Hauser more than the option provided. On the authority of the St. Mary's case. I am of the view that the defence founded upon s. 203 fails. ${ }^{.2}$

Martland J. did not address the point being made by Morrow J.A., that a holder of a right of first refusal does not have an interest in land which may be protected by caveat. He might well have concluded that at the time the dispute arose, the preemptive right had been triggered and was then an equitable interest in land, but the issue was not addressed. The McFarland case can be restricted to the rather peculiar situation where an agreement is made specifically subject to the interest intended to be defeated, but it raises an interesting issue of practical significance. Conveyances and agreements of purchase and sale occasionally provide that an oil and gas property is being acquired "subject to" the lease and all other documents of title. This could result in a purchaser acquiring an asset subject to proprietary and contractual interests arising under the title documents (including preemptive rights and royalties) of which he is not aware. While the vendor has an interest in ensuring that a purchaser will relieve him of his obligations in respect of the asset, language rendering an asset subject to third party rights is not necessary or should be limited to contracts which the vendor is a party to or is otherwise bound.

In 1985 the Alberta legislature entered the debate by amending the Law of Property $A c t^{13}$ by adding section 59.1 which provides that a right of first refusal is an equitable interest in land which can be protected by the registration of a caveat and would thus have the priority afforded to it under section 16 of the Land Titles Act. An interesting issue is whether this amendment was intended to impact freehold land only (and thus the reference to the Land Titles Act) or whether it was intended to entirely overturn the Long Island Petroleums decision in Alberta and make a preemptive right an equitable interest for both patented and unpatented lands. It is, however, important to note that there is no limiting language in the amendment, which suggests that the latter interpretation is more likely.

Although the Long Island Petroleums decision established the current law regarding the nature of preemptive rights, section 59.1 of the Law of Property Act may negate that decision in Alberta (British Columbia has a similar statutory provision). Additionally, the McFarland decision indicates that courts are still struggling with the issue. At least one author has suggested that the issue should be reconsidered, arguing preemptive rights deserve to be classified as proprietary in any event as they can be protected by injunction (a hallmark of a proprietary interest) and in reality are no different than complicated rights of repurchase. ${ }^{14}$

\section{EXCEPTIONS TO PREEMPTIVE RIGHTS}

The CAPL Operating Procedures provide for a number of specified transactions where preemptive rights are inapplicable. Other industry agreements under which preemptive 
rights arise usually list similar exceptions. A few of these exceptions warrant some discussion.

\section{A. ALL OR SUBSTANTIALLY ALL}

The CAPL Operating Procedures exempt any transaction involving the sale of the vendor's entire interest (or an undivided interest) in all or substantially all of the vendor's oil and gas assets. Black's Law Dictionary defines "all" to mean "the whole of - used with a singular noun or pronoun and referring to an amount, quantity." Clearly, "all" means the entirety of something. "Substantially all" is more difficult to define. Black's Law Dictionary defines "substantially" to mean:

Essentially; without material qualification; in the main; in substance; materially; in a substantial manner.

About, actually, competently, and essentially.

Canadian courts have not appended a fixed percentage to what amounts to "substantially all" and in fact have decided the word "substantial" has no inherent meaning. ${ }^{15}$ The case law has treated the consideration of "substantially all" as a question of fact to be determined according to the particular circumstances of each case. The case law is of assistance, however, in illuminating some of the salient factors to be considered in determining the meaning of "substantially all." In Wardean Drilling Co. Ltd. v. Minister of National Revenue, ${ }^{16}$ the Court considered the meaning of "substantially all" in the context of the Income Tax Act. The appellant was claiming a deduction for exploration and development expenses. Prior to making the deductions, the appellant had sold its only producing piece of property (a 5\% interest in two Lsds.) and had retained a $121 \% \%$ undivided interest in six Crown leases which were not producing and subsequently lapsed. One issue before the Court was whether the disposition amounted to a sale of "substantially all" of the appellant's property and the court focused on a comparison of the properties disposed of to those retained.

Cattanach J. considered the area of the lands retained as opposed to those disposed of but indicated that mere quantity, while relevant, was not dispositive of the issue. ${ }^{17}$ The Court held that the disposition did amount to "substantially all" of the appellant's property based on a value-quantitative not area-quantitative theory. ${ }^{18}$ Cattanch J.'s decision was confirmed by the Federal Court of Appeal. ${ }^{19}$ What Wardean does not do is say at what threshold the comparative value of the disposed property becomes substantial. A calculation based on the book values of the properties $(\$ 5,000$ for the $5 \%$ interest and $\$ 640$ for the $121 / 2 \%$ interest) results in a percentage of $88.7 \%$. Thus, in Wardean the appellant had disposed of $88.7 \%$ of its properties by value.

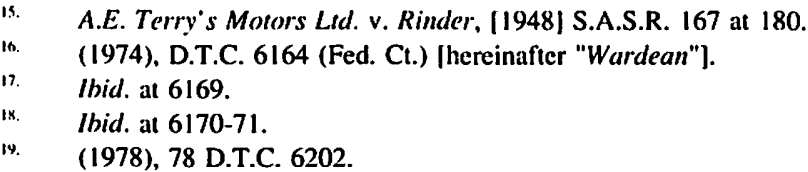


In Re Vanalta Resources Ltd. $^{20}$ the Court dealt with a provision in the British Columbia Companies Act which required shareholder approval for a sale of "the whole or substantially the whole of the undertaking" of the company. Vanalta sold its interest in the North Coleman gas field to one of its affiliates, Hidrogas Ltd. This interest represented about $65 \%$ of Vanalta's total properties. A minority shareholder sought to have the sale set aside because it had not been approved by a special resolution of Vanalta's shareholders. Legg J. stated:

[I]t is in my view that the sale of the North Coleman property was not one which struck at the heart of the corporate existence and purpose of Vanalta."

Vanalta would seem to suggest that something in excess of $65 \%$ of the value of the properties disposed of is required to constitute all or substantially all of the property.

In 85956 Holdings Ltd. v. Fayerman Brothers Limited, ${ }^{22}$ Geatros J. held that the sale of a portion of a corporations assets would destroy the corporate business and, therefore, was substantially all of its property. Geatros J. was less concerned with the quantitative approach than a qualitative approach. He regarded that the primary test should be whether the disposition "would destroy the corporate business." This case must be considered in the context of minority shareholder dissent rights and may not be applicable to preemptive rights in the oil and gas context.

On the disposition of petroleum and natural gas rights under a CAPL Operating Procedure the quantitative (value) approach is more appropriate. One of the purposes of Article 2401(B) is to protect the party holding the right of first refusal from participating interests being sold to "fly-by-night" operators. The exception for "substantially all" petroleum and natural gas rights is acceptable because, presumably, if a party can purchase all or substantially all of one of the participant's rights it must be in at least as good a position as the original participant. Accepting the above argument, the most relevant consideration would be the value of the properties disposed of on a purely valuequantitative basis.

\section{B. AFFILIATES}

The CAPL Operating Procedures provide a definition for an "affiliate" and dispositions to affiliates are exempt from preemptive rights governed by these documents. The definition incorporates the concept of control and this presents a problem in some circumstances. While the 1990 and the 1981 CAPL Operating Procedures explicitly recognize the possibility of indirect control, the 1971 and 1974 Procedures do not address indirect control.

It seems clear that the applicable CAPL Operating Procedures did not intend that "control" meant a majority of voting shares. It would have been a simple matter to state

20. (December 17, 1975), (B.C.S.C.) [unreported].

2. $\quad$ lbid. at 25 .

22. [1985] 2 W.W.R. 647 aff'd (1986), 25 D.L.R. (4th) 119 (Sask. C.A.). 
that affiliate means a corporation, $50 \%$ or more of whose shares are held by the same person or corporation. The fact the procedures do not use such a provision indicates that de facto and not de jure control will be the deciding factor. In general, Canadian jurisprudence which has come down on the side of de jure control involves decisions made pursuant to the Income Tax Act in which the court was trying to determine if closely-held corporations were associated for the purpose of the small-business deduction. The interpretation given taxing statutes has been restricted in regard to the tax payer's right to organize his affairs with some certainty and to relieve against what would be onerous results. Thus, a de jure control test is a simple and certain approach to take in such cases. In addition, cases which turned on a finding of de jure control considered closely held corporations and not publicly traded corporations which have a majority of shares widely disbursed among the public. ${ }^{23}$

In the R. v. Imperial General Properties Limited, ${ }^{24}$ the Court considered whether a corporation whose voting shares were held $50 \%$ by Shareholder $A$ and $50 \%$ by Shareholder B, was associated with Shareholder A. A simple de jure test would have resulted in a finding that the corporations were not associated because neither Shareholder A nor Shareholder B held a majority of the votes. The court, however, imported a de facto element into the test and looked at the quality of the rights associated with each of the blocks of voting shares. While the court denied that it strayed from a de jure test, it seems clear that the " $50+1$ " rule is not the sole test of who controls a corporation. Estey J. stated the de jure test $(50+1)$, and then stated as follows:

Such a distinction, while convenient to express as a guide of sorts in assessing the legal consequences in fashionable circumstances is not, as we shall see, an entirely accurate description of the processes of determination of the absence of control in one or more shareholders for the purpose of Section 39(4). ${ }^{29}$

The court went on to hold that the rights associated with the voting shares of Shareholder B were greater than the rights associated with the shares of Shareholder A and, therefore, even though the shareholders had an equal number of votes, to borrow a phrase from George Orwell's Animal Farm, Shareholder A was "more equal" than Shareholder B. The implication is that control, even in closely held corporations may be de facto control.

For widely held corporations it is submitted that a de facto and not a de jure test for control is the only reasonable test. Such a proposition is supported by Noranda Mines Limited v. The Queen. ${ }^{26}$ In Noranda Mines, the court considered whether Noranda Mines and Orchan Mines Limited were dealing at arm's length. The Court found as a fact, that Noranda did not have de jure control because it held only $45.3 \%$ of the voting shares of Orchan. The Court also considered that the fact two other companies, Pamour Porcupine Mines Limited and Kerr Addison Mines Limited (neither of which Noranda held a majority of shares in) owned an additional $5.53 \%$ of the common shares of Orchan.

23.

Buckerfield's Limited v. M.N.R. (1964), 64 D.T.C. 5301 (Exch. C1.); M.N.R. v. Dworkin Furs (Pembroke) Ltd. (1967), C.T.C. 50, 67 D.T.C. 5035, (S.C.C.).

2. 85 D.T.C. 5500 (S.C.C.).

25. Ibid. at 5502 .

26. 87 D.T.C. 379 (T.C.C.) [hereinafter "Noranda Mines"]. 
The Court held that Noranda had de facto control of Orchan and Bonner T.C.J. stated as follows:

From a practical stand point, Noranda controlled Orchan. It would be unrealistic to suppose, in light of the shareholdings outlined earlier, that Orchan was in a position to act exclusively on the basis of its own perception of its own best interests. It is unlikely that Noranda could ever have been prevented from having its way with Orchan. Anyone seeking to stop Noranda from doing so would have needed to marshal the votes of the $49 \%$ of the shares of Orchan in the hands of the general public and, as well, the votes attached to some, at least, of the shares held by Kerr Addison and Pamour. That person, in seeking to influence the voting of the Orchan shares held by Kerr Addison and Pamour. would be obliged to contend with the fact that Noranda held substantial blocks of shares in each of those two companies and was tied to those companies at will, at least to some extent, by interconnection of directors and officers. The fact that Noranda, from a practical stand point. controlled Orchan is one which, though not determinative, nevertheless weighs heavily against the appellant's position. ${ }^{27}$

It should be emphasized that the tax cases referred to above must be considered in light of the policy of the tax context in which they arose.

In ATCO Ltd. v. Calgary Power Ltd. ${ }^{28}$ the Alberta Court of Appeal held that ATCO controlled a public utility because it owned $58.1 \%$ of a corporation which owned almost all of the shares of three public utilities. The case is authority for the proposition that one company may control another even though it is acting through an intermediary. The British courts have also recognized an "indirect" form of control, where the shareholder controls enough shares directly and indirectly to elect the board of directors. ${ }^{29}$ The 1981 CAPL Operating Procedure provides for deemed control where sufficient shares are held directly or indirectly to elect the majority of a corporations board of directors.

\section{SECURITY FOR INDEBTEDNESS}

Unlike the CAPL Operating Procedures, some preemptive rights (usually found in older agreements) do not provide for an exception from a preemptive right where a party grants an interest in its assets as security for its indebtedness. This leads to confusion regarding the respective rights of the secured party and the holder of the preemptive right. It is highly unlikely that a court would interpret a typical preemptive right clause to give the holder thereof the first opportunity to provide financing and take security. A contrary intention can invariably be inferred from the specific language of the clause. A practical and common solution is to obtain a waiver or consent in the circumstances but this is not always possible. A more interesting question is whether the preemptive right applies when the security is enforced and the property is sold or acquired by the secured party. Some agreements specifically address this possibility. When the agreement is silent, good arguments can be advanced by both sides of the issue, but the issue has not been judicially considered. 


\section{NOTICE AND THE DUTY TO ACQUIRE KNOWLEDGE}

This section deals with the problem of what constitutes "notice" where notice is relevant in the determination of priorities between holders of preemptive rights and subsequent purchasers of the properties subject to those rights. The relevance of notice under the land titles system in Alberta is also reviewed.

\section{A. THE COMMON LAW POSITION}

At common law, the purchaser of real property would be bound by a prior unregistered interest if the purchaser had knowledge of such interest. Actual notice or constructive notice of the prior unregistered interest would bind the subsequent purchaser. ${ }^{30} \mathrm{~A}$ subsequent purchaser would have constructive notice of a prior unregistered interest if he: ${ }^{31}$

(a) had actual notice that there was some encumbrance and a proper enquiry would have revealed what it was; or

(b) deliberately abstained from enquiry in an attempt to avoid having notice; or

(c) omitted by carelessness or for any other reason to make an enquiry which a purchaser acting on skilled advice ought to make and which would have revealed the encumbrance.

There are several ways in which a purchaser may acquire actual notice of a preemptive right:

(a) in a title search prior to the purchase of the properties;

(b) from the vendor in the course of negotiations leading to the acquisition; or

(c) from holders of rights of first refusal.

The test to determine constructive notice is much wider: $:^{32}$

(a) Did the party against whom notice of a fact is asserted have before him such knowledge as ought to have put him on inquiry? and

(b) If he had acted with reasonable business prudence would he have learned of the fact?

The doctrine of constructive notice is a negative doctrine, operating adversely to a person who neglects to inquire. A person is not entitled to claim he had no notice of facts which a reasonable inquiry would have disclosed. ${ }^{33}$ These rather wide tests have been

3. Ryan v. Lockhart (1872), 14 N.B.R. 127 (C.A.); Henderson v. Graves (1862), 2 E \& A 9; Colley v. Smith (1877), 40 U.C.Q.B. 543 (C.A.).

3. R.E. Megarry and W. Wade, The Law' of Real Property, 5th ed. (London: Stevens, 1984) at 148-49. St. John and Que. Ry. Co. v. Bank of B.N.A. (1921), 62 S.C.R. 346, 67 D.L.R. 650, affg 47 N.B.R. 367, 52 D.L.R. 557.

33. Fred T. Brooks Lid. v. Claude Neon Gen. Advertising Ltd., [1931] O.R. 92, [1931] 2 D.L.R. 743; aff'd [1932] O.R. 205, [1932] 2 D.L.R. 45 (C.A.). 
restricted in Canada and, to some extent, in England. ${ }^{34}$ For example, notice of an unusual provision in a mortgage would not be imputed to a purchaser of land if he had notice of the mortgage but had not seen the document. ${ }^{35}$ In the above situation the Court held that the notice must be of such a nature that it would be actual fraud (dishonesty) to disregard it. The question is not whether a party had the means of obtaining, or might by prudent caution have obtained, knowledge, but whether not obtaining knowledge was an act of gross or culpable negligence. ${ }^{36}$

A number of cases have held that a purchaser has a duty to investigate title (Hiern $\mathrm{v}$. Mill $)^{37}$ and use due diligence in his inquiries (Whitbread v. Jordon). ${ }^{38}$ In Jones v. Smith $^{39}$ the Court divided the cases of constructive notice into two categories:

... the cases in which constructive notice has been established, resolve themselves into two classes: First, cases in which the party charged has had actual notice that the property in dispute was ... incumbered or in some way affected, and the Court has thereupon bound him with constructive notice of facts and instruments, to a knowledge of which he would have been led by an inquiry after the charge, incumbrance or other circumstance affecting the property of which he had actual notice; and, secondly, cases in which the Court has been satisfied from the evidence before it that the party charged had designedly abstained from inquiry for the very purpose of avoiding notice. ${ }^{\text {to }}$

The difficult question is when can it be said a purchaser "designedly, abstained from inquiry" to avoid notice? In light of the general industry practice of reviewing title to lands being purchased, a purchaser who abstains from such a review does so at his peril.

\section{B. THE ALBERTA LAND TITLES ACT}

The relevant sections of the Alberta Land Titles Act ${ }^{41}$ are sections 16, 64 and 195. Section 16 establishes priority among caveat holders on the basis of order of registration, section 64 establishes the general rule of indefeasibility and section 195 provides that a person dealing with land need not look beyond the register (except in the case of fraud) and mere knowledge of a competing interest is not of itself fraud. The purpose of section 195 is to negate the application of the doctrines of implied and constructive notice and the equitable fraud rule. The negation of these principles is not a decision Canadian courts take lightly. In United Trust v. Dominion Stores $L t d .^{42}$ the majority of the Supreme Court of Canada held that the doctrine of actual notice, as to all contractual relations and particularly the law of real property, was firmly based in law from the

Ware v. Lord Egmom (1854), 43 E.R. 586; Knight v. Bowyer (1858), 44 E.R. 1053; Wyllie v. Pollen (1863), 46 E.R. 767.

MacDonald v. McLean (1914), 7 W.W.R. 997 (Alta. S.C.T.D.); McNames v. Phillips (1862), 9 Gr. 314.

McDonald v. McDonald (1869) 16 Gr. 37, rev'g 14 Gr. 545 (C.A.).

(1806), 33 E.R. 237.

(1835), 160 E.R. 132.

(1841), 66 E.R. 943.

Ibid. at 948.

R.S.A. 1980, C. L-5.

[1977] 2 S.C.R. 915 [hereinafter "United Trust"]. 
beginning of equity. Such a cardinal principle of property law could not be considered abrogated unless the legislative enactment was in the clearest and most unequivocal of terms. The Court held that provisions of the Ontario Land Titles Act establishing priority according to registration did not purport to repeal the common law.

Alberta Courts have not adopted the interpretation of the Supreme Court of Canada in regard to the similar Alberta provision, because the Ontario and Alberta statutes are quite different. Decisions prior to and after the United Trust case in Alberta have considered actual notice to be abrogated by section 195 of the Alberta Land Titles Act. The Alberta provision differs markedly from the Ontario provision by the addition of "and the knowledge that any trust or unregistered interest is in existence shall not of itself be imputed as fraud." Spence J.A. distinguished the Alberta provision from its Ontario equivalent in that it contains "an express provision making actual notice ineffective to encumber the registered title. ${ }^{n+3}$

For a subsequent purchaser to be bound by a prior unregistered preemptive right under section 195 of the Alberta Land Titles Act, fraud or the knowledge of fraud must be established against the subsequent registered purchaser. Actual knowledge of an unregistered right and acting in a manner which then defeats that right does not constitute fraud in itself. Fraud has been held to mean "actual fraud; dishonesty of some sort." Despite the clarity of section 195 and extensive judicial interpretations of its language, a great number of cases still lead one to believe that it can take very little for the courts to imply fraud in certain circumstances. ${ }^{45}$ There is one other exception to the rule that a subsequent purchaser will not be bound by an unregistered equitable interest. This exception was touched upon in the discussion relating to the McFarland ${ }^{46}$ case and applies when the right acquired is explicitly made subject to the competing interest.

\section{DEFENCES AGAINST PARTY HOLDING PREEMPTIVE RIGHT}

\section{A. THE RULE AGAINST PERPETUITIES}

On the basis of the Long Island Petroleums decision, an argument on the grounds that a preemptive right breaches the rule against perpetuities would be unsuccessful. The holder of a preemptive right has only a contractual right until an offer is made to the vendor which he intends to accept. The option created when such an offer is made is

43

Ibid. al 951.

Assets Company Limited v. Mere Roihi. [1905] A.C. 176, (B.C.) as approved in Ross v. Stovall, [1919] I W.W.R. 673 (Alta. S.C.A.D.).

See, for example. Le Syndicate Lyonnais du Klondyke v. McGrade (1905), 36 S.C.R. 251; Minchan v. Busse, [1940] D.L.R. 282; Sydie v. Saskatchewan \& Battle River Land Co. Lid. \& Brown (1913), 5 W.W.R. 194: Hackworth v. Baker et al. [1936] I W.W.R. 321; Scandia Meat Market Ltd. v. K.D.S. Imestmem Co. Lid., [1977] 1 W.W.R. 542 (Alta. S.C.T.D.); Demers Transport Ltd. v. Fountain Tire Distributors Ltd. |1974| I W.W.R. 348; Zbryski v. City of Calgary (1965), 51 D.L.R. (2d) 54; Ronan v. Derheim. 78 D.L.R. (3d) 682; Krautt v. Paine. [1979] 3 W.W.R. 481; Holt Renfrew \& Co. v. Henry Singer Lid.. [1981] 3 W.W.R. 9 (Alta. Q.B.) appeal dismissed. [1982] 4 W.W.R. 48I.

Supra, note 7. 
generally restricted to a short period of time in the various clauses which gave rise to the preemptive right. The rule against perpetuities is not applicable to personal contracts and therefore there is no possibility of vesting outside of the perpetuity period. In Alberta, however, the issue is confused by section 59.1 of the Law of Property Act ${ }^{47}$ which provides that preemptive rights are equitable interests in land, and a case based on similar facts as Long Island Petroleums might now be decided differently in this Province. However, the Perpetuities Act ${ }^{48}$ would impose a "wait and see" period for agreements taking effect after July 1, 1973.

\section{B. RESTRAINT ON ALIENATION}

In Stephens v. Gulf Oil Canada Ltd.," counsel argued that a right of first refusal was void as a restraint on the power of alienation. A power of alienation is an inseparable incident of a fee simple estate. Any condition annexed to a grant or devise of land in fee simple, which is an absolute restraint on alienation, will be void as repugnant to that estate. ${ }^{50}$ In Stephens, Howland J.A. considered whether the right was a restraint on alienation and made the following comments, distinguishing a right of first refusal at a fixed price:

An option to purchase is more objectionable as a restraint on alienation, than a right of pre-emption. Giving Palen a right of pre-emption is very different from requiring that the property be sold to Palen. or prohibiting its sale without Palen's consent. There would also seem to be a distinction between a preemptive right to meet any offer which is received, and a pre-emptive right exercisable at a fixed price which makes no provision for an increase in the value of the property. The latter provision may involve a very substantial sacrifice by the person who granted it....

In my view, if the right of pre-emption at a fixed price substantially deprives the person who granted it of his right of alienation then it will not be valid. Re Rosher. (1884), 26 Ch. D 801 and Re Cockerill [1929] 2 Ch. 131, were both cases where the disparity between the pre-emptive price and the value of the land was so great that the Court readily concluded that it was tantamount to an absolute restraint on alienation.

In this case Stephens would have been substantially deterred from deciding to sell his property so long as the market value was markedly in excess of the pre-cmptive price. This would also be true during the term of the Agreement for Loan, then Gulf had a prior right of first refusal, unless a mutually satisfactory agreement could be negotiated with Gulf. The right of pre-emption which he granted to Palen substantially deprived Stephens of his right of alienation. If this right of pre-emption was a condition. and not a covenant, then it would be void. ${ }^{\text {s! }}$

47. Supra. note 13.

4x. R.S.A. 1980 , c. P-4.

49. (1975), 65 D.L.R. (3d) 193 (Ont. C.A.) |hereinalter "Stephens").

so. Paul v. Paul (1921), 50 O.L.R. 211, 64 D.L.R. 269: Blackburn v. Mc Callum. , 33 Can. S.C.R. 65. See also. Perell "Options, Rights of Repurchase and Rights of First Refusal as Contracts and as Interests in Land," supra, note 13 at 14-17 for a discussion of the difference between covenants and conditions and the legal conclusion that covenants are not void as restraints on alienation while conditions may be void. 
A similar result was reached in British Columbia Forest Products Ltd. v. Gay. ${ }^{52}$ The rights of first refusal included in CAPL Operating Procedures and other typical industry agreements are not stated at a fixed price and do not "substantially deprive" the grantor of its right of alienation. The argument that typical preemptive rights constitute an invalid restraint on alienation would therefore be unsuccessful.

\section{LIMITATION PERIODS}

Sections 1(e), 4(1)(c)(i), (e), (g) and 18 of the Limitation of Actions ${ }^{53}$ in Alberta are relevant in determining when an action may be commenced by a holder of a preemptive right for an infringement of his rights. Those provisions provide as follows:

I(c) "land" includes

(i) corporeal hereditaments, and

(ii) a freehold or leasehold estate or an interest therein;

4(1) The following actions shall be commenced within and not after the time respectively hereinafter, mentioned:

(c) actions

(i) for the recovery of money, other than a debt charged on land, whether recoverable as a debt or damages or otherwise, and whether on a recognizance, bond, covenant or other specialty or ...

on a simple contract, express or implied, within 6 years after the cause of action arose;

(e) actions grounded on accident, mistake or other equitable ground of relief not hereinbefore specifically dealt with, within 6 years from the discovery of the cause of action;

(g) any other action not in this Act or any other Act specifically provided for, within 6 years after the cause of action therein arose.

18 No person shall take proceedings to recover land except

(a) within 10 years next after the right to do so first accrued to that person (hereinafter called the "claimant"), or

(b) if the right to recover first accrued to a predecessor in title, then within 10 years next after the right accrued to that predecessor.

The provisions leave open the possibility that one of a number of limitation periods is applicable to preemptive rights. For example:

(a) where the right of first refusal relates to an "interest in land" - 10 years after the right to recover first accrued; 
(b)

(c) if the action is for the recovery of money as damages or is not specifically provided for -6 years after the cause of action arose.

The remedy of specific performance is not specifically referred to in the Act.

Notwithstanding that a right of first refusal is an equitable interest in land, the better view is that the ten year limitation period imposed by section 18 does not apply to a claim for specific performance. In Limitation of Actions of Canada, ${ }^{54}$ Williams states that "recovery of land" as contemplated by provincial limitation statutes is a successor to the action in ejectment. The weight of judicial authority bears out this interpretation in restricting the application of section 18 to situations of adverse possession. ${ }^{.5}$

The decision of Western Oil Consultants v. Great Northern Oils Ltd. ${ }^{56}$ involved a claim for specific performance of a royalty agreement which entitled the plaintiff to thirty days notice of the covenantor's intention to surrender any leases and to take assignments of them if it wished to do so. Patterson J. considered the application of section 18 to the enforcement of the preemptive right. Patterson J. found the section inapplicable because, on the authority of Long Island Petroleums, the preemptive right in question did not constitute an interest in land. The implication of this finding is that, had the preemptive right blossomed into an option giving rise to an equitable interest in land, section 18 may have applied. No case law interpreting section 18 was considered by the Court. In light of the large number of reported decisions on section 18 restricted to the issue of adverse possession, this implication may be inaccurate. However, in view of section 59.1 of the Law of Property Act, Patterson J. might now have reached a different conclusion.

Patterson J. rejected the application of section 4(1)(e) which provides for "actions grounded on accident, mistake or other equitable ground of relief" because it continues "not hereinbefore specifically dealt with." He had already found section 4(1)(c)(i) to apply, and therefore held this subsequent subsection could not possibly be applicable in the circumstances. Implicit in his decision is the conclusion that a claim for specific performance is contemplated by section $4(1)(c)(i)$. This too is probably inaccurate inasmuch as the section is clearly restricted to actions for the "recovery of money."

Section 4(1)(e) is particularly important because it permits an action to be commenced "within 6 years from the discovery of the cause of action." The alternative period in section 4 is "within 6 years after the cause of action therein arose." In any case, section 4(1)(e) only appears to cover situations in which equity will grant relief from the consequences of accident or mistake. ${ }^{57}$ It would therefore appear that the appropriate limitation period for holders of rights of first refusal is 6 years after the cause of action

\footnotetext{
s. J.S. Williams, Limitation of Actions in Canada, 2nd ed. (Toronto: Butterworths, 1980) at 88.

ss. $\quad$ Shillabeer v. Diehel (1979), 9 Alta. L.R. (2d) 112 (S.C.T.D.); Freeland v. Freeland (1982), 19 Alta. L.R. (2d) 180 (Q.B.).

56. (1981), 121 D.L.R. (3d) 724 (Alta. Q.B.).

s7. Supra, note 49 at 214.
} 
arose according to Patterson J.'s judgment. However, the argument that Patterson J. incorrectly excluded the application of section $4(1)(e)$ or section 18 should not be overlooked.

\section{COMPLEX PACKAGE}

It is arguable that a preemptive right should not be binding where the burdened land is assigned pursuant to a complex package because of the inherent difficulty of allocating a portion of the consideration to any particular parcel. Some commentators have argued that preferential rights clauses which do not provide an allocation formula might constitute an invalid restraint on alienation in the context of a complex package sale because they inhibit commercial development of oil and gas interests. Additionally, it has been argued that the failure to provide a workable formula for applying the preferential right to a package deal is evidence that the parties did not intend the right to apply to such transactions ${ }^{58}$.

One author describes the onerous situation the owner of a burdened interest is in when the property is sold as part of a package deal:

\footnotetext{
Where the burdened interest is to be sold in a package deal along with other interests not subject to the preferential purchase right, the owner of the burdened interest may be put in an extremely onerous situation. One proper course of action is to give the holder of the right notice of the package sale and to tender to him the interest covered by his preferential purchase right at a sum bearing the same ratio to the total consideration that the value of the burdened interest bears to the total value of the interests sold as a package. Even then, the holder of a right might argue that he had a right to purchase the land at its market value as an individual tract (which could be substantially different) or a right to bid on the entire package. ${ }^{5 y}$
}

This approach was found acceptable by the Ontario Court of Appeal in Budget Car Rentals Toronto Limited v. Petro-Canada Inc. and Gulf Canada Limited. ${ }^{60}$ Budget had leased certain lands from Gulf and the lease included a right of first refusal in favour of Budget which indicated that:

...in the event that the Lessor receives a bona fide offer to purchase the lands and premises herein which it is willing to accept, then in that event it shall so advise the Lessee, showing the Lessee the said, signed offer and giving the Lessee five (5) business days to match the offer and purchase the property... ${ }^{\text {t }}$

Gulf entered into an agreement to sell all of its downstream assets in Western Canada to Petro-Canada, including the land which was the subject matter of the lease. The agreement between Gulf and Petro-Canada provided for a purchase price which exceeded $\$ 300$ million which was not broken down to give an assigned price to any particular Sellingsloh, Preferential Purchase Rights (1966), 11 Rocky Mountain Law Institute 35.

59. Reasoner, ibid, at 73 .

(1). (1989), 60 D.L.R. (4th) 751 (Ont. C.A.) [hereinafter "Budget"].

61. Ihid. at 752. 
property except for certain valuable assets. The land at issue was one of hundreds of parcels of real property acquired by Petro-Canada. At trial, O'Brien J. noted that the transaction was "extremely complex." ${ }^{22}$ Finlayson J.A. of the Court of Appeal held that Gulf had not received a bona fide offer because Gulf did not have in its hands a document which could be presented to Budget for acceptance or rejection. Finlayson J.A. declined to follow two American authorities which rejected this approach and required the vendor to allocate the purchase price ${ }^{63}$ stating that allocation was not possible. It is respectfully submitted that allocation was (and always is) possible; the decision itself identified three possible measures of the value of the property.

Sautkulis v. Matzok, a New York decision which also held that a preferential purchase provision is inapplicable to a package sale, was not referred to in the Budget case. In Capalongo v. Giles $^{6.5}$ the New York Supreme Court concluded that a vendor had a duty to offer the whole parcel to the holder of a preemptive right on a portion of the parcel. The result in the Capalongo case becomes absurd where more than one party holds a right of first refusal in different portions of a package transaction. Must the vendor then offer the whole package to each of the holders of rights of first refusal?

The Budget case is arguably contrary to the practice of most oil and gas corporations which typically allocate the purchase price to lands subject to preemptive rights even where the transaction involves a large number of properties. On the other hand, the Ontario Court of Appeal distinguished the U.S. authorities on the basis that allocation was easily accomplished there but impossible in the Budget case. Budget may not be adopted by other courts in Canada (Brooke J.A. decided the case on a separate issue and declined to join Finlayson and Griffiths JJ.A.) or it might be restricted to instances where the transaction is so complex that allocation is not appropriate or possible. If so restricted, Budget would not apply to most oil and gas conveyances.

\section{E. UNMATCHABLE CONSIDERATION}

Consideration has been given to the possible argument that preemptive rights are inapplicable when a significant part of the consideration for the transfer is unmatchable by the person asserting the right. The CAPL Operating Procedures exception clauses, however, require the assignor to give a bona fide cash estimate of the value of the noncash consideration. Disputes as to the reasonableness of the estimates are to be submitted to arbitration. In that the contract expressly contemplates the possibility of unmatchable consideration, the presence of unmatchable consideration is not sufficient to except an assignment from the preferential rights clause. Some agreements, however, may not expressly deal with the problem of unmatchable consideration. The holder of the right of first refusal simply has the right to acquire the subject interest upon the same terms and conditions as the seller is willing to sell to the third party. If the holder cannot match

Ihid. at 754.

Garmo v. Clanton (1976), 551 P. 2d 1332 (Idaho Supreme Court); Brenner v. Duncan (1947), 27 N.W. 2d 320 (Michigan Supreme Court).

(1956), 1 App. Div. 2d 962, 150 N.Y.S. 2d 356, aff d (1957) 2 N.Y. 2d 919, 141 N.E. 2d 916.

(1980), 425 N.Y.S. 2d 225 [hereinafter "Capalongo"]. 
those terms and conditions, the argument is stronger that the preemptive right is inapplicable.

In any case, there appears to be a duty to "translate" any sort of consideration into a cash price which can be offered to the party holding the right of first refusal. In Manchester Ship Canal Company v. Manchester Racecourse Company, the Court showed its willingness to allow the racecourse to accept a "mixed price" of cash and other consideration, subject to the canal company's right of first refusal. Apparently, however, the selling company must be able and willing to translate that mixed price into a cash price equivalent for the party holding the right of first refusal:

We do not decide that the Racecourse Company could only negotiate with the Trafford Park Company for an exclusively cash price; but we do decide that even if the Racecourse Company could negotiate for a mixed price, yet the cash price at which they offer the land to the Canal Company for acceptance or refusal must not exceed the total of the cash price at which they have offered the land to the third person, plus the reasonable cash value of the option which they take as part of the purchase price. ${ }^{\text {to }}$

\section{F. EQUITABLE DEFENCES}

\section{Estoppel}

The equitable doctrine of estoppel by acquiescence (or proprietary estoppel) relates to the situation where a person having an interest in land allows another party to do some act upon the land to that party's detriment. The estoppel is founded upon the first party allowing the detriment to the second party to increase unnecessarily. ${ }^{67}$ The test for proprietary estoppel was set forth by Fry J. in Willmott v. Barber: ${ }^{68}$

It has been said that the acquiescence which will deprive a man of his legal rights must amount to fraud, and in my view that is an abbreviated statement of a very true proposition. A man is not to be deprived of his legal rights unless he has acted in such a way as would make it fraudulent for him to set up those rights. What, then, are the elements or requisites necessary to constitute fraud of that description? In the first place the plaintiff must have made a mistake as to his legal rights. Secondly, the plaintiff must have expended some money or must have done some act (not necessarily upon the defendant's land) on the faith of his mistaken belief. Thirdly, the defendant, the possessor of the legal right, must know of the existence of his own right which is inconsistent with the right claimed by the plaintiff. If he does not know of it he is in the same position as the plaintiff, and the doctrine of acquiescence is founded upon conduct with the knowledge of your legal rights. Fourthly, the defendant, the possessor of the legal rights, must know of the plaintiff's mistaken belief of his rights. If he does not, there is nothing which upon to assert his own rights. Lastly, the defendant, the possessor of the legal right, must have encouraged the plaintiff in his expenditure of money or in the other acts which he has done, either directly or by abstaining from asserting his legal right. Where all these elements exist, there is fraud of

67. Anger and Honsherger: Law of Real Property, 2d ed. (Aurora, Ont.: Canada Law Book, 1985) at 1469. 
such a nature as will entitle the Court to restrain the possessor of a legal right from exercising it, but, in my judgment, nothing short of this will do. ${ }^{69}$

As noted in Anger and Honsherger: Law of Real Property the five criteria are strictly applicable only when the person sought to be estopped has acquiesced or silently stood by. Specific fact situations may remove the need to prove all of the criteria. ${ }^{70}$

In a situation where the preemptive right holder believes a disposition notice is invalid but does nothing, allowing the applicable time period to elapse, it may be possible to invoke the doctrine of proprietary estoppel if the party attempts to enforce his rights in the future. Of course to succeed, the party asserting the doctrine would have to meet the five criteria set forth above.

An argument may also be made based on promissory estoppel. This arises where one party makes a representation by word or conduct which is intended to be acted upon and is acted upon by the other party to its detriment. ${ }^{71}$ It may be argued that holders of preemptive rights are estopped from exercising their rights when they had notice of a transaction which triggered the right but failed to act. To be successful in asserting this defence, it must be demonstrated that the holder of the preemptive right, by action or conduct, evinced an intention not to insist on his legal rights knowing that the vendor and purchaser would and did act on that belief in completing the transaction. Canadian courts are reluctant to construe silence or inaction as evidence of a party's intentions. There are a number of Canadian cases, however, which considered the argument that a party who received notice by letter or other means should be estopped from asserting his legal rights because he failed to respond to such notice. ${ }^{72}$ Generally, mere delay will not disentitle a party from relief ${ }^{33}$ and a vendor or purchaser would likely not succeed on an estoppel defence if he was aware of the right of the holder of the preemptive right or was aware that such right had not been properly complied with. ${ }^{74}$ For example, a vendor who gives notice of a proposed disposition to a preemptive right holder with knowledge that the purchase price has been overstated, could not later assert estoppel when such holder becomes aware of the true price and purports to exercise the right. Finally, there is a good argument that, as between the preemptive right holder and the purchaser, the defence of promissory estoppel cannot be raised. The purpose of promissory estoppel was to prevent the terms of a contract from being varied without consideration; the estoppel does not create the contractual relationship. ${ }^{75}$ We know of no decisions where title to realty

Ibid. at 105.

Supra, note 67 at 1470.

D \& C Builders Lid. v. Rees. [1966] 2 Q.B. 617, [1965] 3 All E.R. 837 (C.A.).

See: Grimsby Steel Furniture Co. Limited v. Columbia Gramophone Co. (1922), 23 O.W.N. 188; City of Kitchener v. Allen Theatres (1922), 22 O.W.N. 231 (C.A.); Edelson Libin Insurance Limited v. Lino Catering Limited (1977), 5 A.R. 626; Winearls v. Hoey, [1917] 2 W.W.R. 287 (Man. Co. Ct): Ewing v. The Dominion Bank (1901), 35 S.C.R. 133; Vancouver Key Business Machines Lid. v. Teja (1975), 57 D.L.R. (3d) 464; Spencer. Bower \& Tumer, Law Relating to Estoppel by Representation, 2nd ed. (London: Butterworths, 1966) at 474.

Pioneer Tractor Co. Lid. v. Peebles (1913), 15 D.L.R. 275 (Sask S.C.).

16 Hals., (4th ed.), para. 1474.

Zeisman v. W.P.W. Developments Lid. (1976), 78 D.L.R. (3d) 619 (B.C.S.C.). 
has been defended based on promissory estoppel, but estoppel by acquiescence does not suffer the same defect. ${ }^{76}$

\section{Laches}

Laches may also be raised as a defence to a claim brought by the holder of a preemptive right. This doctrine is often referred to as a type of estoppel and the elements of both are substantially similar. In any situation where no limitation period is expressly applicable to an equitable claim, the defendant may claim the doctrine of laches will apply. The Limitation of Actions Act likely precludes the operation of this doctrine. ${ }^{77}$ "Laches essentially consists of a substantial lapse of time coupled with the existence of circumstances which make it inequitable to enforce the claim." ${ }^{.78}$ A court will refuse its aid to "stale demands," where the plaintiff did not enforce his rights and acquiesced for a great length of time. ${ }^{79}$

To determine whether an actual delay amounts to laches, the following two points must be considered; first, acquiescence on the plaintiff's part, and second, any change of position that has occurred on the defendant's part. Acquiescence does not mean standing by while the violation of a right is in progress, but assent after the violation is completed and the plaintiff has become aware of it. To be unjust, the plaintiff's conduct must be regarded as equivalent to a waiver of a remedy. Acquiescence implies that the person acquiescing is aware of his rights and is in a position to complain of an infringement of them.

\section{REMEDIES AVAILABLE TO A PARTY HOLDING A PREEMPTIVE RIGHT}

\section{A. INJUNCTION}

If the holder of a preemptive right believes that the property which is the subject matter of his right is being disposed of in contravention of that right, he may ask a court for a restrictive injunction preventing the disposition of the property until his right is complied with. Injunctions are usually not awarded where damages are the proper remedy, but this is not an issue where land is involved (see discussion below on specific performance); there is a strong judicial preference towards injunction where a defendant has wrongfully interfered with the plaintiff's property rights. ${ }^{80}$ The plaintiff's obligation to establish irreparable harm (generally a pre-requisite to the award of an injunction) can also be met if the object of the dispute is real property. This was the result of Manchester Ship Canal Company v. Manchester Racecourse Company,, ${ }^{81}$ where the English Court of Appeal refused to give an intended purchaser specific performance of a purchase and sale

\footnotetext{
76. Western Fish Products Lud. v. Penwith D.C. |1981| 2 All E.R. 204.

77. Supra, notc 54 and accompanying text.

78. Sinells Principles of Equity (London: Sweet \& Maxwell, 1990) at 33.

7\%. 16 Hals. (4th ed.), para. 1476.

xi. D. Bean, Injunctions (London: Longman Group UK Lid., 1987) at 13.

xi. Supra, note 1 .
} 
agreement because, in doing so, the sale would breach the right of first refusal contained in a prior contract between the vendor and a third party. An injunction was granted to the holder of the right of first refusal to stop the sale.

\section{B. SPECIFIC PERFORMANCE}

\section{Entitlement to Remedy}

The general rule of contract remedies is that, so far as possible, the courts should put the plaintiff in the position he would have been in had the contract been performed. This goal may be achieved by awarding the injured party compensatory damages or ordering the defaulting party specifically to perform its obligation. The primary remedy for breach of contract remains the award of monetary compensation, with specific enforcement being available only where monetary compensation is not adequate. ${ }^{82}$

The buyer of land has historically been held to be entitled to specific performance on the principle that each plot of land is unique. ${ }^{83}$ In Flint v. Corby, ${ }^{84}$ Esten, V.C. explained this principle as follows:

The specific performance of an agreement respecting land, is enforced because the court intends in every particular instance that the estate, which forms the subject matter of the contract, possesses a peculiar value for the purchaser, and that pecuniary damages will fumish no adequate equivalent for the loss of his bargain. In this case the peculiar value. which attracts the jurisdiction of the court, is implied and needs not be proved. ${ }^{\text {ss }}$

An oil and gas lease is a profit a prendre, or a right to take something from the soil of another ${ }^{86}$ and therefore constitutes an interest in land. As such, a preemptive right which has become an option to acquire an interest in an oil and gas lease or is an equitable interest in land pursuant to section 59.1 of the Law of Property Act, would appear to fall within the line of cases where specific performance is the appropriate remedy. The Supreme Court of Canada applied these principles in Long Island Petroleums, and determined that the holder of the preemptive right was entitled to specific performance unless the transferee of title could show it had obtained title without notice of the covenant. Martland J. justified granting specific performance after conveyance of the interest on these grounds:

In this case Sadim did convey its interest in the land to Long Island, which took its title with full knowledge of the requirements of the restrictive covenant. This being so, 1 do not consider that the

Stewart v. Kennedy (1890), 15 App. Cas. 75 (H.L.); Wilson v. Northampton \& Banbury Junction Ry. Co. (1874), 9 Ch. App. 279.

к3. Adderley v. Dixon (1824), I Sim. \& St. 607, 57 E.R. 239; Buxton v. Lister (1746), 3 Atk. 383.26 E.R. 1020.

s. (1853), 4 Gr. 45.

s.s. Ihid. at 52.

\$. Berkheiser v. Berkheiser, [1957] S.C.R. 387, 7 D.L.R. (2d) 721 (S.C.C.). 
position of Long Island as against the respondents should be improved because Sadim had actually acted in breach of its commitment to the respondents, by assigning its interest to Canadian Long Island. ${ }^{87}$

In McFarland, one issue which was discussed was whether an order for specific performance could be granted against the optionee, because there was no privity of contract between the optionee and the holder of the right of first refusal. The Supreme Court of Canada concluded that the problem did not arise here because the title had remained throughout with the defendant, with whom the holder of the right of first refusal had contracted. At the Alberta Court of Appeal, Morrow J. (Moir J. concurring) relied on the following quotation from Purchase v. Lichfield Brewery Co.:

It is impossible that a specific performance of a contract can be decreed against a person with whom there is neither privity of contract nor privity of estate. ${ }^{\mathrm{kx}}$

It is respectively submitted that Morrow $J$. failed to recognize that, once an offer had been accepted by the defendant, an interest in land was created and privity of contract was no longer a problem.

Although Martland J. saw no difficulty in granting specific performance in Long Island Petroleums, some recent Canadian authorities suggest that specific performance will not be so readily granted in the future, simply because land is involved. ${ }^{89}$ In Long Island Petroleums the parties had agreed in their statement of facts that the purchaser was in a position to convey to the holder of the right of first refusal the interest in the event they

Supra, note 2 at 737.

[1915] 1 B. 184 at 189.

89.

For example, in Heron Bay Investments Ltd. v. Peel-Elder Developments Ltd. (1976), 2 C.P.C. 338 (Ont. H.C.J.) Weatherstonn J. restricted the remedy of specific performance in the following manner (at 339):

The remedy of specific performance is one that is peculiar to real estate transactions and is based on the fact that real estate is regarded as unique and of particular importance to the purchaser ... That reasoning does not apply when land is purchased merely as an investment ... True it may be a uniquely good investment, but it was not being purchased by the plaintiffs for their own use but only to develop and resell at a profit. Obviously, any loss of profits can be compensated for in damages.

Similarly, in Chaulk v. Fairview Construction Ltd. (1977), 14 Nfld. \& P.E.I.R. 13 (Nfld. C.A.), Gushue J.A. stated (at 21):

There was nothing whatever unique or irreplaceable about the houses and lots bargained for. They were merely subdivision lots with houses, all of the same general design, built on them, which the respondent was purchasing for investment or re-sale purposes only ... It would be quite different if we were dealing with a house or houses which were of a particular architectural design, or were situated in a particularly desirable location, but this was certainly not the case.

See also McNabh v. Smith (1981), 124 D.L.R. (3d) 547 (B.C.S.C.), affd (1982), 132 D.L.R. (3d) 523n (B.C.A.A.); 306793 Ontario Lid. v. Rimes (1979), 100 D.L.R. (3d) 350 (Ont. C.A.), 25 O.R. (2d) 79; Prittie v. Laughton (1902), I O.W.R. 185 (Div. Ct.); Loan Investment Corp. of Australasia v. Bonner, [1970] N.S.L.R. 724 (P.C.)). It is, however, still clear that specific performance is almost always granted; Kloepfer Wholesale Hardware \& Automotive Co. Lid. v. Roy, [1952] 2 S.C.R. 465, [1952] 3 D.L.R. 705 (S.C.C.). 
were entitled to specific performance. The Court did not discuss the advantages or disadvantages of the alternative damage remedy.

Holders of preemptive rights generally purchase oil and gas interests for the purposes of investment, and, therefore, the proposition that substitutes cannot be found and that damages are inadequate is questionable. ${ }^{90}$ Holders of preemptive rights would have no subjective attachment to the land, although they could argue that their own judgment as to the income producing qualities of the land make it unique for their purposes. Further, a substitute in the market may not offer the same income producing qualities as the land bargained for or may not create the same efficiencies achieved by buying an additional interest in a property. This last point is important insofar as preemptive rights in the oil and gas industry almost always arise out of joint ownership of property.

Section 20 of the Judicature $A c t^{91}$ is relevant to this issue and states:

20. In all cases in which the Court has jurisdiction to entertain an application:

(a) for an injunction against:

(i) a breach of a covenant, contract or agreement, or

(ii) the commission or continuance of a wrongful act, or

(b) for the specific performance of a covenant, contract or agreement,

the Court if it thinks fit may award damages to the injured party either in addition to or in substitution for the injunction or specific performance, and the damages may be ascertained in any manner the Court may direct, or the Court may grant any other relief that it considers just.

This provision, and similar provisions across Canada, are seldom referred to or relied upon. ${ }^{92}$ The courts have done little to capitalize on the discretionary power afforded by these statutory provisions, and have, subject to the exceptions cited earlier, been content to rely on the long standing rules of common law and award specific performance whenever land is at issue.

\section{Estoppel and Laches}

As discussed above, a delay or failure by a third party in asserting his preemptive right may cause a court to preclude him from exercising that right. The doctrines of estoppel and laches may be applied to preclude the remedy of specific performance but allow a claim for damages to proceed. The application of these equitable defences to deny specific performance would depend on the specifics facts of each case.

See P.J. Brenner, "Specific Performance of Contracts for the Sale of Land Purchased for Resale or Investment" (1978) 24 McGill L.J. 513.

9. R.S.A. 1980 c. J-I.

92. $\quad$ See Trawick v. Mastromonaco (1983), 24 Alta. L.R. (2d) 389. 


\section{DAMAGES}

Canadian courts have only touched upon the complicated problems involved in the calculation of damages for breach of a preemptive right in the oil and gas context. Four issues are of particular importance here:

1. A person wrongfully deprived of property should recover its "value" less the "contract price." What is the "value" of the property?

2. What is the proper date for the assessment of the value of the property?

3. How should the holder of a preemptive right be compensated if the property has been developed and value has been added? and

4. In assessing damages should the defendant be given credit for interest on the unpaid purchase money?

\section{The Value of Property}

Damages are generally measured by the difference between the value and the contract price (if the former is larger) and market price is the usual measure of value. ${ }^{93}$ Oil and gas properties have no perfect substitute, and no mechanism or market exists that can precisely determine their value. Joint owners of resource assets bargain to give each other the right of first refusal to purchase an interest in an oil and gas lease at an acceptable contract price which in most cases may be argued to be market value. If market value and the contract price are the same and market value is the appropriate test of damages, the holders of rights of first refusal would not be entitled to any compensatory damages for loss of property. Nevertheless, the holders of preemptive rights could argue that there is some additional value to them in acquiring a further interest in property in which they already hold an interest. This subjective measure of value is shown in two ways:

the efficiency of increasing an existing interest may make the property worth more than "market value" to the holder of a right of first refusal; and the holder of a preemptive right may hope to avoid a particular purchaser for one reason or another.

While courts generally have been hesitant to adopt a subjective measure (because of the inherent difficulties in calculation) there is some authority to support a subjective definition of value in certain circumstances. ${ }^{94}$

\section{Date for Assessment of Damages}

The second issue involves the date of the assessment of damages. The choice of date of assessment is important where the value of the property, of which the holder of the 
preemptive right has been deprived, changes between the date of the breach and the date of judgment. If the value of the property has declined, and damages are assessed at the date of the wrong, the plaintiff will be put in a better position than if the wrong had not been done, and vice versa.

In Solloway v. McLaughlin's5 shares were converted and then replaced by the defendant in a falling market. The plaintiff would not have dealt with the shares in the interim. The Court held that the right to damages was measured at the date of conversion, and only reduced by the value of the replaced shares at the date of the replacement. This windfall to the plaintiff is explained by Waddams ${ }^{96}$ as a method by which the Court overcomes the greater harm than good that would result in an inquiry into what the plaintiff would have done with the property if the defendant had delivered it. The cost of such an inquiry is simply too high. Similarly, where property values have increased between the date of the wrong and the date of the judgment, courts have preferred early crystallization. ${ }^{97}$

In Asamera Oil Corp. Ltd. v. Sea Oil \& General Corp., ${ }^{98}$ the Supreme Court held that on a failure by a bailee to return shares, the owner was not entitled to recover damages based on the value of shares after a date at which he could reasonably have replaced them in the market.99 The Court supported its conclusion on principles of mitigation; concluding that the buyer could reasonably have avoided the loss he claimed by buying a substitute in the market on the seller's default.

Cases have held that a buyer is entitled to wait until it is clear that the seller will not deliver before mitigating by purchasing substitute property. ${ }^{1(x)}$ If the defendant offers assurances of eventual performance it will be reasonable for the buyer to postpone the purchase of a substitute, and not unjust to hold the defendant to the higher price at a later date. In Asamera Oil, a six year period was permitted because it appeared that the defendant had urged the plaintiff to postpone litigation. In Wroth v. Tyler, ${ }^{101}$ damages arising out of a botched home purchase were measured at the date of judgment, after the market price had risen. Waddams criticizes the application of Wroth v. Tyler ${ }^{102}$ and that decision may be restricted to the situation where the purchaser is unable to mitigate its loss by the purchase of a substitute property. Commercial purchasers who are capable of mitigating their losses should arguably be excluded from the benefit of a postponed assessment. On the other hand, the very reason specific enforcement is usually granted (uniqueness of the asset) argues against this conclusion.

[1938] A.C. 247, [1937] 4 D.L.R. 593 (P.C.).

S.M. Waddams, The Law of Damages (Toronto: Canada Law Book. 1983) at 84.

Asamera Oil Corp. Lid. v. Sea Oil \& General Corp.. [1979] I S.C.R. 633; Radford v. De Froherville. [1977] I W.L.R. 1262 (Ch. D).

Ibid.

Reaffirmed in Johmson v. Agnew', [1980] A.C. 367 (H.L.).

Ogle v. Earl Vane (1867), L.R. 2 Q.B. 275, aff'd (1868), 3 Q.B. 272 (Ex. Ch.); Wilson v. London \& Globe Finance Corp. Lid. (1897), 14 T.L.R. 15 (C.A.): Samuel v. Black Lake Ashestos \& Chrome Co. (192I), 62 S.C.R. 472,63 D.L.R. 617 (S.C.C.).

[1974] Ch. 30.

Supra, note 96 para. 86-87. 
Cases in Canada dealing with rights of first refusal or options have seldom dealt with the damage question because specific performance has usually been granted. In Westward Farms Ltd. v. Cadieux the Manitoba Court of Queen's Bench (rev'd on other grounds) held that damages for breach of contract to give the plaintiff an option to buy land were assessed at the date a reasonable person might have purchased a substitute. This was held to be six months. The Wroth v. Tyler decision was rejected by the Court because four years had elapsed from the date of the breach to the date of the judgment, making it unfair to calculate damages at the date of judgment.

In Vanc'suver Key Business Machines, ${ }^{103}$ the British Columbia Supreme Court held that the claim for specific performance and damages for breach of a right of first refusal failed because of estoppel. In obiter, Verchere J. expressed his view that the Wroth $\mathbf{v}$. Tyler case was not applicable for two reasons:

(i) the plaintiff had contemplated a rise in house prices, while here there was no evidence of such a state of mind; and

(ii) the plaintiff's inability to mitigate their loss was known to the defendant.

The Court therefore held that damages should be measured on the difference between the contract price, which was the sale price, and the estimated value of the property when the alleged breach was properly discovered.

A more recent Alberta decision came to the opposite result. In Western Oil Consultants v. Great Northern Oils Ltd. ${ }^{104}$ the Alberta Court of Queen's Bench considered a situation where the defendant had surrendered oil and gas leases in breach of a term of a royalty agreement that the plaintiff was to be given notice of surrender and have an opportunity to take assignments if desired. The case of Wroth v. Tyler was relied upon as authority for the proposition that the date of trial is the proper date for assessment where the remedy of specific performance would have been appropriate, but for the impossibility of achievement. Damages were calculated on the date of trial. This decision is important because it pertains to oil and gas assets and because the right breached was substantially similar to a typical preemptive right.

\section{Value Added to Property}

The problem of added value is significant if the holder of a preemptive right is granted specific performance or if damages are assessed at a later date, after the value of the property has been enhanced. Should an allowance be made for improvements made on the property by the defendants? 
In Alberta, s. 60 of the Law of Property Act ${ }^{105}$ presents a statutory answer to this question by providing that:

60(1) When a person at any time has made lasting improvements on land under the belief that the land was his own, he or his assigns

(a) are entitled to a lien on the land to the extent of the amount by which the value of the land is enhanced by the improvements, or

(b) are entitled to or may be required to retain the land if the Court is of the opinion or requires that this should be done having regard to what is just under all circumstances of the case.

(2) The person entitled or required to retain the land shall pay any compensation that the Court may direct.

This remedial legislation has been interpreted broadly by Alberta courts, thereby providing strong protection for the party who improves the land. For instance, while application of the section had in the past been limited to bona fides mistakes in title, it has since been expanded to include mistakes in identity of the property. ${ }^{106}$ In order to use the provision successfully, though, the belief of the improver that he owns the land must be reasonable. ${ }^{107}$ Moreover, the improvement made must be "lasting," which has been interpreted as meaning that it is either permanent, or not easily removable. ${ }^{108} \mathrm{We}$ are not aware of any application of the provision relating directly to oil and gas properties, however, improvements which have met the statutory threshold of being "lasting" include a retaining wall and bunkhouse, ${ }^{109}$ a foundation for a cottage and the cleaning of undergrowth. ${ }^{110}$

The use of this statutory remedy by a party who has improved land subject to a preemptive right may be barred if the party had knowledge of the right, or knowledge that its claim to title was in dispute. This is due to the fact that its belief in ownership would not be bona fide. Such was the situation in the celebrated case of International Corona Resources Ltd. v. Lac Minerals Ltd."' in which Lac had placed a mine and mill on property which Corona claimed. Lac claimed a lien on the improvements it had made, based on s. 37(1) of the Ontario Conveyancing and Law of Property Act ${ }^{112}$, which is similar to the Alberta provision. The Ontario Court of Appeal held that the section was inapplicable because the improvements made were after the date on which a certificate

R.S.A. 1980, c. L-8, s. 60. Similar provisions are found in the legislation of other provinces. See, for example: in Ontario, the Conveyancing and Law of Property Act, R.S.O. 1980, c. 90, s. 37(1); in Manitoba s. 27 of Law of Property Act, L.R.M. 1987, c. L90; and in Saskatchewan, the Improvement Under Mistake of Tille Act, R.S.S. 1978, C. 1-1, s. 2. Mildenherger v. Prpic, [1976] 4 W.W.R. 67, 67 D.L.R. (3d) 67 (Alta.). Maly v. Ukranian Catholic Episcopal Corporation of Western Canada (1977). 6 Alta. L.R. (2d) 277. See also Gay v. Wierzhicki, [1966] 2 O.R. 372 at 375, reversed [1967] 2 O.R. 211, 63 D.L.R. (2d) 88 (Ont. C.A.).

110. Maly v. Ukrainian Catholic Episcopal Corporation of Western Canada, supra, note 107.

III. International Corona Resources Lid. v. Lac Mincrals Ltd. (1986), 32 B.L.R. 15, 53 O.R. (2d) 737. 39 R.P.R. 113, 25 D.L.R. (4th) 504, 9 C.P.R. (3d) 7 (H.C.). Affd (1987), 46 R.P.R. 109, affd (1989), 26 C.P.R. (3d) 97, 69 O.R. (2d) 287, 61 D.L.R. (4th) 14 (S.C.C.).

112. R.S.O. 1980 , c. 90 . 
of lis pendens in respect of Corona's claim to the property was registered. Therefore, Lac was aware of a potential weakness in its title. However, the Court did allow for reimbursement of the cost of improvements based on the proprietary remedy of restitution. That is, without restitution through a constructive trust, Corona would have been unjustly enriched, especially given the two companys' similar objectives for the site. ${ }^{113}$ Obviously, a similar argument could be made by a resource company which had developed a property subject to a preemptive right.

Of course, the issue of whether a constructive trust should be imposed to redress unjust enrichment leads to a debate of whether it is unreasonable to require the plaintiff to pay for unrequested improvements. Waddams argues that an allowance is justified because the plaintiff should only recover such a sum as would put him in the position he would have occupied had he sought to sue the wrongdoer immediately. ${ }^{14}$ In the following passage, Waddams attempts to reconcile the law of restitution which tends to favour a person who improves another's property, and the general rule that an owner cannot be made to pay for unrequested benefits:

\begin{abstract}
In those cases, therefore, where an allowance is properly made for the defendant's improvements in calculating damages, it is suggested that the law of restitution should allow the improver to recover if the plaintiff regains possession of the goods. It does not necessarily follow that every improvement must in all circumstances be compensated. Where the owner is in possession of goods for personal use it will usually not be just to compel him to pay for unrequested benefits. Commercial benefits, however, ought usually to be paid for, since they represent a pecuniary gain to the recipient, and it is no imposition upon him to compel repayment of the equivalent moncy value."1s
\end{abstract}

\title{
4. Interest on Unpaid Purchase Money
}

The fourth issue regarding damages relates to interest on the unpaid purchase price and is very important if specific performance is granted, or damages are calculated at the date of judgment in accordance with Wroth v. Tyler. No such allowance was mentioned in Wroth v. Tyler, although without such an allowance, the purchasers were overcompensated. As stated by Waddams:

The effect of allowing the purchaser to claim damages based on the appreciated value of the land without paying interest on the unpaid price is to permit the purchaser to acquire the profits of holding the land during the period in question without accounting for the profits of holding the price. ${ }^{116}$

In 306793 Ontario Ltd. v. Rines ${ }^{117}$ the Court rejected any allowance for interest saved by the purchaser by the postponement of payment of the purchase price. The Court appeared to incorrectly assume that no benefit was derived because the purchaser did not

The Ontario Court of Appeal's decision on this issue was upheld by the Supreme Court of Canada. however, the Court made no comment on the applicability of the statutory provision.

Supra, note 96 at 30 , para. $54-55$.

Ihid. at 30, para. 55.

Supra, note 96 at 65, para. 115.

(1979), 25 O.R. (2d) 79, 100 D.L.R. (3d) 350 (C.A.). 
have the money in hand. However, in that case the vendor expressly abandoned this claim, arguing the matter in terms of a possible reduction in damages in respect of carrying charges. Mackinnon A.C.J.O. made two points:

that the vendor had possession of the land between breach and trial and should bear the incidental costs; and

(b) that damages in lieu of specific performance must be equivalent to the economic effect of the decree, which does not permit such an allowance.

Waddams argues that a similar order should attach to a decree of specific performance and that the first argument was also not convincing because damages in lieu of specific performance would give the vendor all the profit of holding the land. ${ }^{18}$ Waddams' conclusions, although without judicial support, are sound in light of compensatory principles.

\section{PRACTICAL PROBLEMS}

\section{A. ADEQUACY OF NOTICE}

One problem that often arises in regard to preemptive rights is the adequacy of the disposition notice. If the notice is defective the notice period will not run against the preemptive right-holder. In analyzing this problem we have used the $1981 \mathrm{CAPL}$ Operating Procedure clause 2401 B ("Clause 2401 B") as being representative. We have also compared the 1990 CAPL Operating Procedure Clause 2401 B ("1990 Clause") and noted the different obligations regarding notice.

Clause 2401 B provides that "the selling party's notice shall contain the terms and conditions of the proposed assignment, sale or disposition, including the consideration to be received for the subject interest and, if applicable, the name of the offering party." It is our experience that very few notices given provide all the terms and conditions of the sale. Generally, the notice provides the name of the proposed purchaser, the lands, the consideration, adjustments, allocation of consideration and the closing and effective dates. Parties holding 1981 CAPL preemptive rights seem to have unilaterally interpreted Clause 2401 B to mean "basic" terms and conditions.

There is little support in the actual words of Clause 2401 B for such an interpretation. A holder of a preemptive right who receives such a notice and desires more time to evaluate the lands in question would be well advised to claim the notice is ineffective because it does not contain "the terms and conditions" of the proposed disposition. Additionally, the basic terms may not provide a preemptive right-holder with terms that may affect his decision to exercise his right. For example, a relatively low price disclosed in a notice may not be as attractive if the purchaser is to assume all liability for environmental damage. Representations and warranties in a sale agreement are normally the subject of great debate, yet parties rarely disclose those terms in the disposition notice. 
A notice which provides just the basic terms may give rise to a variety of problems. What are the parties' positions if a notice is sent to a preemptive right-holder, who purportedly waives his right to exercise by signing and returning the notice? The generally accepted wisdom in the industry is that by signing and returning the notice the preemptive right-holder has waived his right to exercise. However, if the notice is ineffective, for not providing "the terms and conditions" of the disposition, arguably no notice has been received by the preemptive right-holder and the waiver of his right is also ineffective, his decision having been based on a nullity. A potential result is that the preemptive right continues to exist and the holder of that right could, at a later date, attempt to enforce his right subject to all of the defences described above.

A stronger case may be put forward by the party who simply does nothing and allows the notice period to lapse. As noted above, Canadian courts have been reluctant to interpret silence as affirmation of a state of facts. In both cases, however, the preemptive right-holder puts himself in a difficult position either by signing the notice or doing nothing. Arguments that the right-holder is estopped from asserting his right, or has lost his right by the passage of time (laches), would, given industry practice, be persuasive to a court (particularly an Alberta court). The result, however, is far from clear.

A good argument can be made that disposition notices which provide only the basic terms do not comply with Clause 2401 B and therefore may be ineffective. The clause expressly requires "the terms and conditions" not the "material," "pertinent" or "relevant" terms and conditions. To avoid that risk and to fulfil the literal obligations under Clause $2401 \mathrm{~B}$, the sale agreement should be provided to the preemptive right-holder.

While some industry members are currently providing sale agreements to preemptive right-holders, others are resistant to such a practice. An alternative, albeit one that is not without risk, would be to make a copy of the sale agreement available to the preemptive right-holder at the vendor's office for review. The issue is whether Clause $2401 \mathrm{~B}$ has been complied with and if "making available" is the same as "giving notice." However, Clause 2401 B states that the notice "shall contain the terms and conditions" of the disposition and not a road map on how to find out those terms and conditions. Practically, the parties will likely be able to work out an arrangement to review the sale agreement, however, a preemptive right-holder would likely be within his rights to demand strict compliance with Clause 2401 B.

Problems may even arise when the sale agreement is attached to the notice. If the sale agreement is amended (after the notice has been sent to the preemptive right-holders) which changes the "terms and conditions" of the transaction, then the original notice may be ineffective for not having disclosed the actual terms and conditions of the disposition. The transaction which triggered the right, and which was subsequently waived, no longer exists. The new transaction triggers a separate right and a new notice should be served. A court, faced with such a fact situation, would likely be inclined to imply a de minimis threshold on changes. 
The 1990 Clause is substantially different from the 1981 provision but may cause similar problems. It does not require that the notice contain "the terms and conditions" of the disposition but requires that the notice contain the following information:

(a) description of working interest being sold;

(b) identity of the proposed purchaser;

(c) the consideration for the disposition;

(d) the effective and closing dates; and

(e) "any other information respecting the transaction which the disposing party reasonably believes would be material to the exercise of the offerees' rights hereunder."

The thrust of the 1990 Clause appears to be that the complete sale agreement need not be attached. The issue to be addressed is what "information" is "material?" Can an offeree argue that "information" is much broader than "terms and conditions" and the seller is required to disclose material information not otherwise provided in the sale agreement? For example, where a proposed sale is on an "as is where is" basis (the typical receivership sale) and the vendor expressly provides in the sale agreement that the purchaser shall assume all environmental liability, is the vendor obligated to inform the preemptive right-holders (even though he has not informed the purchaser) that there is a serious environmental problem that is "material" to the value of the lands? Is the failure to disclose that "material information" a defect in the notice? The intent of the 1990 Clause, at first blush, would appear to remove the requirement to disclose all terms and conditions of the sale agreement. However, the more generic terms (material information) may present a whole new mine field of problems quite apart from the sale agreement.

Finally, the 1990 Clause provides that if the notice of disposition is accepted by the preemptive right-holder a binding contract of sale is created on the terms and conditions "in the disposition notice." The right of first refusal holder should be wary of accepting the terms in the disposition notice without asking for all the terms and conditions normally found in a sale agreement. According to the 1990 Clause, a preemptive right-holder has no right to insist on a formal sale agreement and may be bound by the basic terms of the disposition notice, which does not contain the normal representations, warranties and indemnities found in a sale agreement. On the other hand, a disposition notice provided under a 1981 CAPL Operating Procedure that contains only the basic terms may, in fact, be a notice to negotiate the actual terms and conditions of a sale agreement.

\section{B. ALLOCATION OF PURCHASE PRICE}

One common issue which arises when preemptive rights apply to a portion of a package of properties is the allocation of the purchase price among the preemptive right lands and the other lands. This issue does not arise if a vendor is not bound to allocate and while this issue is subject to doubt, industry practice generally assumes that allocation among properties in a package is required. As discussed above, value is subjective and a person may have reasons peculiar to him which make a particular property more or less valuable. Further, a vendor and purchaser both have an interest in discouraging the exercise of preemptive rights: the purchaser wants the property he bargained for and the 
vendor wants to avoid the cost of additional transactions. Often the result is that the portion of the purchase price allocated to the preemptive right assets exceeds, on an equivalent cash flow or reserve estimate basis, that portion of the purchase price allocated to the other assets. For example, a prospective purchaser may achieve operating efficiencies only if the entire package is acquired. In other words, the whole is worth more than the sum of the parts and the value of the preemptive rights lands is arrived at by determining the value of the non-preemptive rights lands by themselves and subtracting this amount from the entire price. The difference (which is in effect a disproportionate allocation) becomes the value of the preemptive rights lands.

This should only be the result where the disproportionate allocation is based on some legitimate reason, but people's perceptions of what is a reasonable or unreasonable basis for a disproportionate allocation differ. As a practical matter, if you are a vendor or a purchaser, one way to avoid a challenge of an allocation is not to disclose the total purchase price in the notice. The vendor's and purchaser's positions may also be improved by using separate agreements for the preemptive right lands and the other lands which are not linked contractually. Another possibility is to include in the sale agreement a "generic" method of allocating the purchase price which takes into consideration the very factors which arguably favour a disproportionate allocation. These latter approaches are very difficult to attack unless it can be demonstrated that the vendor and purchaser have colluded to allocate a disproportionate percentage of the purchase price to the preemptive rights lands on a basis which is not reasonable.

The holder of a preemptive right basically must demonstrate that the price indicated in the notice is not the actual purchase price for the assets, but is a contrived price intended to thwart his right. The holder runs a risk of losing the property if he elects to challenge the notice instead of exercising his right and the price set forth in the notice is later determined to be valid. The holder may, however, be able to halt a transaction (insofar as it pertains to the preemptive right lands) simply by challenging the notice. A purchaser could argue that this challenge constitutes a cloud on title and the sale agreement may entitle him to exclude the asset at closing or terminate the transaction.

\section{TRUSTEE, AGENT HOLDING RIGHT}

Another problem relates to the situation where one party acts as agent or trustee for other parties and is best described in an example. Parties $\mathrm{A}$ and $\mathrm{B}$ enter into a participation agreement (the sub-agreement) whereby $A$ agrees to act as agent and trustee for B. Any lands A acquires will be on behalf of itself and B. The agreement contains a standard right of first refusal. A acquires an interest in lands owned by $\mathrm{C}$ and enters into an operating agreement (the head agreement) which contains a Clause 2401 B right of first refusal. B decides to sell its interest in the lands to $\mathrm{X}$.

In the above situation there may be some discussion as to who is entitled to receive notice of the disposition. First of all, it has been argued by some industry members that the transactions which take place behind $\mathrm{A}$, who is a party to the head agreement, are irrelevant to $C$ because the interest held by $A$ has not changed and therefore $C$, vis a vis $\mathrm{A}$, is in no worse a position than it was in prior to the disposition by B. As a practical 
matter $\mathrm{C}$ may have difficulty even discovering the transaction. It is argued that only $\mathrm{A}$ should receive notice of the disposition according to the sub-agreement. However, the above position does not recognize the legal nature of a right of first refusal and the disposition may be attacked by $\mathrm{C}$.

A entered into the head agreement as agent and trustee of $\mathrm{B}$ and thereby bound it contractually to the terms of that agreement and the agreement is enforceable by $C$ against B. The right of first refusal between $A$ and $B$ ranks behind the right of first refusal between $A$ and $C$, because when $A$ acquired an interest in $C$ 's lands he acquired that interest subject to the terms and conditions of the agreement governing the lands. B can be in no better position than $A$ and its rights are subordinate to the rights affecting $C$ 's lands. Thus the notice should go to $C$ from $A$ as trustee and agent of $B$ and to $A$ from $\mathrm{B}$, subject to C's right to exercise.

Additionally, C's right, once triggered by B's intention to dispose of its interest, or pursuant to section 59.1 of the Law of Property Act, is an interest in land and is enforceable directly against $B$ and $X$ because the right is an in rem and not an in personam right.

\section{LANDS AND TANGIBLES SPLIT}

Occasionally an oil and gas lawyer may be faced with the peculiar situation where the lands and the tangibles are subject to two separate rights of first refusal. While normally the plant agreement will provide an exception for the situation where the lands served by the plant are sold, that is not always the case.

The dilemma for the purchaser and the vendor is how to avoid only acquiring or being left with either the lands or the plant. One method which may be effective depends on whether the plant is being used to its full capacity. If it is, and the other partners want to obtain more capacity in the plant to process gas from their lands, the purchaser may be at risk if the value he allocates to the plant is based on the plant and lands being purchased as a unit. Instead, the purchaser should allocate the consideration to the assets based on the assumption that the lands, without the plant, are worth less because: first, without plant capacity a processing fee would have to paid; and second, the ERCB pronouncement against the proliferation of gas plants may prevent him from building his own plant. Thus, in order to reduce the risk of acquiring the lands without the plant a premium is allocated to the value of the plant and the consideration is accordingly higher. It can be appreciated that such a procedure is fraught with danger. The appropriate allocation will be difficult and remain no guarantee that a purchaser will acquire both the lands and the plant. Other parties may also challenge the allocation which would delay or prevent the entire transaction from going forward. In many cases the risks may be unacceptable. It may also be possible to argue that the agreement for sale for both the lands and facilities is a "complex package" within the meaning of Budget ${ }^{119}$ because it 
is, in the words of the Ontario Court of Appeal, impossible to allocate a value when the values are interdependent.

Another potential solution is to make the sale conditional on the rights of first refusal in the lands and plant both being waived. In such a way the purchaser would not be required to close the transaction unless he acquired both the plant and the lands. However, the vendor is then in the same position as the purchaser was in the above example. Once having sent out the notices for the lands and plant, if a party exercised its right (in the plant for example) the vendor would have a binding obligation to convey its interest in the plant to that party. If no rights were exercised in the lands the purchaser would not be obligated to close the deal and the vendor would be left with the lands but without plant capacity.

It is submitted that in this situation it is not unreasonable, and comes within the words of the agreement, that the condition that the rights of first refusal must be exercised on both the lands and the plant is a bona fide condition of each of the disposition notices. Normally, it would be inappropriate to attach conditions to the sale of a right of first refusal property which relate to the purchase of other assets or terms and conditions not related to the right of first refusal property. For example, could a condition set forth in the notice require the preemptive right-holder to purchase all other assets being sold to the potential purchaser or to assume a lease of office space or to hire field employees? Certainly some conditions are appropriate. For example, a condition that the holder assume all environmental liability (provided that the purchaser has agreed to that term) would be appropriate. Arguably, the appropriateness of any condition is that it has some nexus to the right of first refusal property, otherwise a preemptive right-holder's interest would be vulnerable to circumvention.

However, where the two assets are so closely related that the value of each is tied inextricably to the other, the nexus warrants that the sale of one be conditional on the sale of the other. The notice reflects the actual terms and conditions upon which the purchaser is prepared to buy and the vendor is prepared to sell the assets. In this situation the preemptive right-holder in the plant, for example, is not obligated to take the lands, but the offer to him from the vendor is that the plant will only be sold to him if the lands are also disposed of.

A similar situation is where one of the assets (for example the plant) is subject to a right of first refusal and the other (for example the lands) are not. If the purchaser wants all or nothing, the vendor, to be adequately protected, must make the disposition notice subject to the condition that the preemptive right-holder who exercises must also acquire a proportionate share of the lands. In this situation the condition is more onerous because it contemplates the plant owner actually being required to buy the lands himself, not merely that the preemptive rights on the lands also be exercised. For example, a leasing company that owns no lands but has, through default under the lease of the plant equipment, come into possession of an interest in the equipment may want the additional capacity but not the lands. 
The argument in this situation is again that the nexus between the lands and plant is such that the condition is a bona fide condition of the sale. As a practical matter, where the purchaser does not have to balance the allocation between lands and plant because of competing rights of first refusal, he likely will be more inclined to place a higher premium on the value of the plant. Assuming that the premium can be justified (based on the reasons discussed above) a purchaser may be able to reduce his risk in that manner.

However, in the above situations there is no clear cut solution. The holders of preemptive rights have a sound argument that a disposition notice which hinges on the sale of some other asset, not subject to the agreement which they are parties to, is not within the meaning of the right of first refusal clause (see the example above). It can be argued that the agreement in question is only to apply to the disposition of the asset governed by it. Had the parties intended to create an exception for adjoining lands, not only could they have done so, it is customary in the industry to do so. It follows that to make the sale conditional on the sale of a separately governed, albeit related, asset operates to create an exception to the right of first refusal clause that the parties chose not to insert in the agreement.

While the possibility of the above situation may be remote, it presents problems which are not easily resolved.

\section{E. THE "BUTTERFLY"}

The CAPL Operating Procedures and a number of other typical industry preemptive rights clauses contain exceptions for conveyances to affiliates, conveyances of all or substantially all of a party's assets, mergers and amalgamations. For tax reasons, a number of vendors choose to dispose of assets through butterfly transactions whereby the assets are sold to a wholly owned subsidiary ("Subco") and the shares of Subco are sold to the Purchaser. Subco may continue to hold the assets, it might be amalgamated with the purchaser or it may be wound up and its assets distributed to the purchaser. Arguably, preemptive rights do not apply insofar as there is an applicable exception for each specific step in the transaction. This argument is technically correct and judicial bias in favour of strictly construing the terms of options also adds support. Further, it could be contended that the transaction is complex and the result in Budget is appropriate. No "offer" has been made for the assets as the price for the shares cannot be equated with the price for the assets. To the contrary, holders of preemptive rights would argue that the steps of the butterfly transaction must be looked at together and their effect is no different than a simple conveyance.

Courts would likely be reluctant to allow a party to do indirectly what he cannot do directly, especially if the indirect steps are taken to avoid a preemptive right, rather than to achieve a tax driven objective. If the transaction is not tax driven, Subco could simply sell all of its assets to the purchaser. Denying the holder of a preemptive right the opportunity to exercise in these circumstances would defeat one of the purposes of the right, which is to allow a joint owner the opportunity to choose his partners. The oil and gas industry, out of caution or an acceptance of the latter position, usually gives notice 
of butterfly type transactions to the holders of preemptive rights, offering them the opportunity to acquire the shares of Subco.

No court has addressed the issue of whether a right of first refusal applies to butterfly or step transactions. Another issue which has not been addressed is whether the holder of a preemptive right could force a sale of the assets, as opposed to a sale of shares of Subco. In view of the uncertainty involved, the best approach for vendors and purchasers is to continue to assume that preemptive rights apply to butterfly transactions. The vendor gets his money either way and both parties gain certainty and reduce risk. From the preemptive right-holder's perspective, if he challenges the notice on the basis that he is entitled to buy the assets directly (as opposed to the shares), he will be confronted with the argument that the right is inapplicable for the reasons discussed above. The price of the shares will likely be less than the price of the assets for tax reasons and the holder of the preemptive right should be satisfied with the opportunity to buy the shares.

\section{F. ASSIGNMENT OF A PREEMPTIVE RIGHT}

One interesting problem arises when a purchaser enters into an agreement to acquire lands subject to a preemptive right and, prior to the closing or prior to the recognition of the purchaser as a party to the agreement under which the right arises, the vendor ("vendor 1") is served with a notice of a preemptive right by a third party ("vendor 2"). Arguably the purchaser has no independent right to exercise the right of first refusal and he may instruct vendor 1 to exercise the right. Must a third notice then be sent out by vendor 1 on the basis that there are or will be two conveyances (one from vendor 2 to vendor 1 and one from vendor 1 to the purchaser)? Does the assignment of a right of first refusal itself (as opposed to the asset which is the subject matter thereof) trigger a right of first refusal on the basis that the right is an equitable interest in the land? The 1981 CAPL preemptive right is triggered if a party proposes to dispose of "all or part of its interest" and this suggests the answer to both questions is yes. If the second purchaser who has agreed to acquire an interest from vendor 2 instructs vendor 2 to exercise the third notice, then a fourth notice must be given and a circle of preemptive rights is created until one of the two purchasers is recognized under the relevant agreement and can exercise the right directly. The 1990 CAPL preemptive right is only triggered by the disposition of a "working interest," but it does not seem appropriate to allow an assignment of a preemptive right as this could ultimately defeat the intent of the right itself. Nevertheless, the language of the 1990 CAPL leaves open this possibility.

The contrary argument is that once the transaction is closed (all rights of first refusal having been waived or lapsed), but before the purchaser is recognized in the agreement under which the preemptive right arises, the vendor is the agent of the purchaser. Additionally, many sale agreements expressly provide that from the effective time to the closing time the vendor is acting as agent for the purchaser. If another party gives a disposition notice to the vendor, the purchaser has the right to instruct the vendor to exercise the preemptive right on its behalf as agent of the purchaser. No further notice of a disposition would be required as the vendor would be exercising the right as the agent of the purchaser. 
If a disposition notice is sent to a vendor before closing, the issues are more complex but arguably the result is the same. The potential purchaser (if the sale agreement is signed) has an equitable interest in the land and the rights attached to the land. The disposition notice transforms the right of first refusal into a legal option to purchase held by the vendor. The purchaser thus acquires an equitable interest in the option. A problem may arise if the vendor refuses to exercise the right because the purchaser may not be able to compel the vendor to exercise the right if the sale agreement does not provide that the vendor will act as the purchaser's agent during the interim period.

\section{CONCLUSION}

The uncertainty created by the application of preemptive rights clauses to complex transactions and valuation problems suggests that vendors and purchasers should proceed cautiously, especially in view of the remedies available to the holders of preemptive rights. To a certain extent common industry practice reflects this cautious approach. On the other hand, a paucity of case law suggests that the decisions of vendors and purchasers are seldom challenged and these parties might be more aggressive when interpreting preemptive rights clauses to favour their position. 